ANDRADE, A. R. S.; FRANCO, E. S.; GUERRA, H. O. C.; JADOSKI, S. O.; SILVA, E. G.; CRUZ, A. F. S.; FERREIRA, M. E. S.; SILVA, E. T.; SOARES, H. R. Chemical fertilization through fertirrigation in the evaluation of the biochemical charact eristics of the watermelonfruits Revistade Agricultura Neotropical, Cassilândia-MS, v. 8, n. 3, e5561, jul./set. 2021. ISSN 2358-6303. DOI: https://doi.org/10.32404/rean.v8i3.5561.

\title{
Chemical fertilization through fertirrigation in the evaluation of the biochemical characteristics of the watermelon fruits
}

\author{
Antonio Ricardo Santos de Andrade1, Euler Soares Franco², Hugo Orlando Carvallo Guerra ${ }^{3}$, \\ Sidnei Osmar Jadoski ${ }^{4}$, Edijailson Gonçalves da Silva ${ }^{1}$, Adiel Felipe da Silva Cruz ${ }^{5}$, Maria \\ Emanuele da Silva Ferreira ${ }^{1}$, Edes Torres da Silva ${ }^{1}$, Hammady Ramalho e Soares ${ }^{5}$ \\ ${ }^{1}$ Universidade Federal do Agreste de Pernambuco, Garanhuns, Pernambuco, Brasil. E-mail: ricoarsa@ gmail.com, \\ edijailsongoncalves@gmail.com, emanuely.darck@gmail.com, edestorres@gmail.com \\ ${ }^{2}$ Faculdade de Ciências Sociais Aplicadas, Campus Itararé, Campina Grande, Paraíba, Brasil. E-mail: eulersfranco@yahoo.com.br \\ ${ }^{3}$ Universidade Federal de Campina Grande, Campina Grande, Paraíba, Brasil. E-mail: hugo_carvallo@ hotmail.com \\ ${ }^{4}$ Universidade Estadual do Centro Oeste, Campus Cedeteg, Guarapuava, Paraná, Brasil. E-mail: sjadoski@unicentro.br \\ ${ }^{5}$ Universidade Federal Rural de Pernambuco, Unidade Acadêmica de Garanhuns, Garanhuns, Pernambuco, Brasil. E-mail: \\ felipe.adiel@gmail.com, hresoares@hotmail.com
}

Received: 29/09/2020; Accepted: 20/05/2021.

\section{ABSTRACT}

The objective of this work was to evaluate the effects of splitting in three different doses of phosphorus and potassium, combined with each other, and it was applied fertirrigation in watermelon crop, and to evaluate their effects on fruit quality. The statistical was in a complete randomized block design, and the treatments were arranged in a factorial scheme $(3 \times 3)$ in subdivided splits, resulting in 9 treatments with tree replications, totaling 27 plots in the experimental area. In the horizontal plots the three doses of phosphorus fertilization $\left(100,150\right.$ and $300 \mathrm{~kg} . \mathrm{ha}^{-}$ ${ }^{1}$ of $\left.\mathrm{P}_{2} \mathrm{O}_{5}\right)$ were randomly allocated, and in the subplots the three potassium doses $\left(50,100\right.$ and $\left.200 \mathrm{~kg} \cdot \mathrm{ha}^{-1} \mathrm{of} \mathrm{K}_{2} \mathrm{O}\right)$, were applied in fertirrigation. The cultivar used was Crimson Sweet. Seventy-Six days after planting (DAP) the biochemical characteristics of watermelon fruits were evaluated: total soluble solids (TSS), total treatable acidity (TTA) and potential of hydrogen $(\mathrm{pH})$. According to the results, it was verified that only the chemic al value of the TSS fruits, presented significant statisticaldifferences between the studied doses because of the different source of fertilization $\mathrm{K}$ and $\mathrm{P}$ increased the soluble solid contents, the content of reducing sugars, and decreased $\mathrm{pH}$. It was observed the different doses of $\mathrm{K}$ and $\mathrm{P}$ did not influence in the fruit quality parameters when it was analyzed separated: TTA and $\mathrm{pH}$ but the TTA values are according to consumer market standards. The best doses in order to economy of fertilizer were $\left(150 \mathrm{~kg} \mathrm{ha}^{-1}\right.$ de $\mathrm{P}_{2} \mathrm{O}_{5}$ e $50 \mathrm{~kg} \mathrm{ha}^{-1}$ of $\left.\mathrm{K}_{2} \mathrm{O}\right)$.

Keywords: Fertilizing, Crims on Sweet, Plant Nutrition, Soil Fertility

\section{Chemical fertilization through fertirrigation in the evaluation of the biochemical characteristics of the watermelon fruits}

\section{RESUMO}

Objetivo deste trabalho foi avaliar os efeitos do parcelamento em três doses de fósforo e potássio, combinados entre si, aplicados via fertirrigação na cultura da melancia, e avaliar os efeitos destas sobre a qualidade dos frutos. O delineamento utilizado foi de blocos ao acaso, com os tratamentos arranjados no esquema fatorial (3x3) em parcela subdivididas, resultando em 9 tratamentos, com 3 repetições, totalizando 27 parcelas na área do experimento. Nas parcelas horizontais foram alocadas de forma aleatorizadas as três doses da adubação de fósforo (100, 150 e 300 $\mathrm{kg} \cdot \mathrm{ha}^{-1}$ de $\mathrm{P}_{2} \mathrm{O}_{5}$ ), e nas subparcelas as três doses potássio $\left(50,100\right.$ e $200 \mathrm{~kg}$ ha $^{-1}$ de $\mathrm{K}_{2} \mathrm{O}$ ), foram aplicados na fertirrigação. A cultivar utilizada foi a Crims on Sweet. Ao final de 76 dias após plan tio (DAP) foram avaliadas as características bioquímicas dos frutos da melancia: sólidos solúveis totais (SST), acidez total titulável (TTA) e potencial hidrogeniônico $(\mathrm{pH})$. Pelos resultados obtidos verificou-se que somente os valores químicos dos frutos de SST, apresentam diferenças significativas entre as doses estudadas, pois as diferentes fontes de adubação de K e P aumentou o teor de sólidos solúveis, os açúcares redutores, e diminuiu do pH. Observou -se que as diferentes doses de P e K não influenciaramisoladamente nos parâmetros de qualidade dos frutos:TTA e pH, porémos valores da TTA estão dentro dos padrões do mercado consumidor. As melhores doses vis ando à economia dos insumos são (150 kg ha-1 de $\mathrm{P}_{2} \mathrm{O}_{5}$ e $50 \mathrm{~kg} \mathrm{ha}^{-1}$ de $\mathrm{K}_{2} \mathrm{O}$ ).

Palavras-chave: Adubação, Crims on Sweet, Nutrição de plantas, Fertilidade do Solo. 


\section{Introduction}

Watermelon (Citrullus lanatus L.) belongs to the cucurbit family and originates from the African continent. It is an annual plant, of low growth, with several ramifications that reach up to $5 \mathrm{~m}$ of length, it is an olive tree species cultivated practically in almost all the Brazilian states, in particular in the Northeast region, where it presents excellent adaptation, because the local climatic conditions are very similar to the conditions of origin, probably Equatorial Africa (Andrade Junior, et al., 2006).

There is little statistical information on watermelon cultivation with chemical fertilization management through fertirrigation, however, according to data from the United Nations Food and Agriculture Organization (Faostat, 2019), show that China, Iran, Turkey and Brazil are the world's largest producers of watermelon, together accounting for $75 \%$ of production. Around 118 million tons of fruit are produced worldwide. The main importing countries are the United States, Germany, Canada, China and France, which accumulated over 50\% of world imports in 2018. However, the largest fruit exporting countries are not their largest producers, in this ranking, Spain is in the first place, followed by Iran, Mexico, Italy and the United States. Brazilian watermelon production ranks fourth among the olerícolas, corresponding to 105,064 hectares of harvested area and production of 2.3 million tons. The main watermelon producing regions of the country are the Northeast and the South, which contribute, respectively, with $18 \%$ and $35 \%$ of the total national production, highlighting the states of Pernambuco, Bahia, Rio Grande do Norte. The Southeast region accounts for $14 \%$ of the national production highlighted in Rio Grande do Sul (Ibge, 2016; Agrianual, 2017).

Despite the importance of watermelon for the country and, above all, for the Northeast region, the productivity of this crop is very variable among producers and, in most cases, low in relation to the productive potential of the crop, due to several factors, among them the inadequate management of the crop, the water deficit and incorrect fertilization, reflecting in low fruit productivity (Amaral, 2011). One of the main factors of low productivity and fruit quality is the inadequate management of crop nutrition. Among the nutrients, potassium (K) and phosphorus $(\mathrm{P})$ are the nutrients most absorbed by the plant (Oliveira et al., 2015)

In watermelon culture, mineral nutrition is one of the most important factors because it directly contributes to the productivity and quality of the fruits. Fertilization is a preponderant point in the increase in the quality of watermelon fruits, and an unbalanced fertilization has caused damage to production and damage to the physical and chemical characteristics of the soil (Souza, 2014).
Potassium $(\mathrm{K})$ is the nutrient most extracted from the soil by melons (45\%), fruit from the same family as watermelon, and its deficiency reduces root growth, increases plant mating, plant susceptibility and decreases resistance to water stress (Almeida et al., 2014). Excess gives the plants symptoms similar to excess salinity, in addition to the occurrence of induced calcium and magnesium deficiency (Souza, 2014). Potassium also influences the quality characteristics of watermelon, as it is indispens able for the formation and ripening of the fruits and for the increase of their texture (Lucena et al., 2011). This nutrient plays a relevant role in the melon yield, but the excess can cause vegetative development of little vigor, fruits of lower average mass and premature maturation, decreasing phosphorus as similation (Souza, 2014).

Phosphorus participates in the formation of roots, flowering and higher fructification, and in its deficiency there is a decrease in the production, quality and early senescence of plants. According to Dias et al. (2001), phosphorus provides greater fruit size and superior quality. The amount of phosphorus required by watermelons is a key factor in achieving high productivity. The response to phosphate fertilization depends, among other factors, on the availability of phosphorus in the soil, on the availability of other nutrients and on climatic conditions (Martinhão et al., 2004). According to the same authors, phosphorus fixation by calcium (Ca) is minimal due to its acid character, and after dissolution occurs, practically all phosphorus $(\mathrm{P})$ is retained in the solid phase, forming les $\mathrm{s}$ soluble compounds and low efficiency of phosphorus fertilization.

For watermelon cultivation, fertirrigation has a higher productivity than water irrigation, in addition to decreasing production costs, increasing the efficiency of the fertilization process, decreasing leaching losses, as well as soil losses due to erosion (Castilhos, 2012). Fertirrigation has been used almost throughout the country in agricultural centers producing fruit and vegetables. The supply of fertilizers through irrigation water opens up new possibilities for a better control of the nutritional needs of crops. (Azevedo et al., 2016). The response of melancholy to nitrogen depends on the applied dose, form of fertilizer application (manual application or fertirrigation), cultivar and soil and climatic conditions of the experiment, being common indications of $\mathrm{N}$, ranging from 80 to $300 \mathrm{~kg} \mathrm{ha}^{-1}$ (Morais et al., 2008; Araújo et al., 2011).

Fertirrigation increases the efficiency of fertilization which decreases the cost of production by saving labor, allowing it to be fractionated without costing, and at the right time, thus increasing, the production and productivity values satisfactory according to the dosages of different nutrients depending on solubility and according to the recommendation for the region of 
Agreste Pernambucano (Villas Bôas et al., 2001). According to Andrade Júnior et al. (2007), the main problem of fertirrigation is associated with incorrect management, due to the lack of adequate information and/or utilization, empirically.

In many regions, the rapid adoption of the technique of fertirrigation, caused the practice to advance the investigation and with this arose the problems; unfortunately, this fact has implied in reduction of productivity and discouragement to the use of fertilization via irrigation water, by some producers, mainly for producers in the Agreste Meridional region of Pernambuco, specifically in the municipality of Garanhuns/PE, do not have information on the necess ary doses of nutrients to achieve the maximum yield of watermelon, mainly in relation to the new cultivars introduced in the region (Souza, 2014). Thus, the introduction or adaptation of fertilizer application techniques ( $\mathrm{P}$ and $\mathrm{K}$ ), already used, can contribute to the achievement of greater productivity and production quality, reflecting the economic efficiency of the activity without damage to the environment, make this agricultural practice sustainable.

Therefore, the adequacy of the dose of $\mathrm{P}$ and $\mathrm{K}$ to the culture via irrigation water is of paramount importance, since it is directly related to the productivity and quality of the fruits, profitability of the crop (production cost) and the impact on the environment. In this context, the objective was to evaluate the quality of watermelon fruits cultivated Crimson Sweet (Citrullus lanatus L) cultivated in field, submitted different doses of phos phorus and potassium (PK), under fertirrigation, and used localized irrigation system, taking into account biochemical parameters by means of biometric measures of the fruits.

\section{Material and Methods}

The experiment was conducted in the experimental area of the Rural Federal University of Pernambuco, Academic Unit of Garanhuns (UAG/UFRPE), Brazil, whose located in the following geographic coordinates: latitude $8^{\circ} 53^{\prime} 25^{\prime \prime}$ south and longitude $36^{\circ} 29^{\prime} 34^{\prime \prime}$ west. The soil characterization of the experimental area was classified as a dystrophic Yellow Latosol according to the Brazilian Soil Classification System (Embrapa, 1999). Chemical and physical analyzes of this soil were performed in the soil laboratory of the Federal University of Campina Grande (UFCG), in samples taken at depths from 0 to $20 \mathrm{~cm}$.

The Crims on Sweet cultivar was used because it has a low habit with ramifications, which can reach 3 to 5 meters in length and the roots develop in a horizontal direction, concentrating in the $25-30 \mathrm{~cm}$ surface of the soil, although some roots reach greater depths Besides the Crimson Sweet cultivar stands out for being highly demanding on this nutrient, which increases the need for research on it, and for being one of the main cucurbits grown in Brazil, more specifically in the Northeast, Midwest and Southeast regions; the Northeast is responsible for $35 \%$ of the national production (IBGE, 2016).

Sowing in the field, leaving 3 seeds per pit per meter of furrows, in the adopted spacing was $3.0 \mathrm{~m}$ between lines and $1.5 \mathrm{~m}$ between plants. Twelve days after the emergence, when the seedlings were with two definitive leaves, the thinning was performed, leaving only one plant per linear meter. Preventive phytosanitary control was performed weekly, using products and doses appropriate to the eventualities; in addition to spraying with agricultural pesticides, weeds were performed aiming to control weeds; the fruits were protected with plastic to avoid direct contact with soil moisture and consequent rotting, conferring better quality of the bark.

The doses of $\mathrm{K}$ and $\mathrm{P}$ fertilizers in each crop cycle were defined according to soil analyses (Castilhos, 2012). Nutrient parceling was done in order to synchronize fertilizer applications to the demand of the plants, in the different stages of crop development. For the culture cycle, the required amount was three doses of phos phorus according to the treatments studied $(100,150$ and $300 \mathrm{~kg} \mathrm{ha}^{-1}$ of $\mathrm{P}_{2} \mathrm{O}_{5}$ ) combined with the three doses of potassium fertilization $(50,100$ and $200 \mathrm{~kg}$ ha- 1 of $\mathrm{K}_{2} \mathrm{O}$ ).

The application of the doses of each treatment of $\mathrm{P}$ and $\mathrm{K}$ occurred through the use of drip irrigation system, using monoammonium phosphate - MAP as water soluble phosphate sources ( $10 \%$ of $\mathrm{N}$ and $53 \%$ of $\left.\mathrm{P}_{2} \mathrm{O}_{5}\right)$ with a solubility of $44 \mathrm{~kg} / 100 \mathrm{~L}$ and potassium chloride $\mathrm{KCl}\left(48 \% \mathrm{Cl}\right.$ and $\left.60 \% \mathrm{~K}_{2} \mathrm{O}\right)$ soluble in water at 34 $\mathrm{kg} / 100 \mathrm{~L}$ (Senar, 2019). A dose of $126 \mathrm{Kg} \mathrm{ha}^{-1}$ of $\mathrm{N}$ via fertirrigation was also applied to meet the needs of the plant, considering the amount of $\mathrm{N}$ applied via the MAP source.

The application of the fertilizers was performed via irrigation water, with weekly watering shift throughout the watermelon phenological cycle, using TMB type fertilizer injection pump combined Venturi injector, installed on a trestle in the main line, through two bypass tanks, connected in separate irrigation networks, one corresponding to potassium fertilization treatments, and the other, phos phate fertilization treatments.

The quantities of fertilisers $\mathrm{K}$ and $\mathrm{P}$ have been applied in accordance with the treatments, the distribution of which has been made over the cycle, established fromthe nutrient uptake march by the watermelon crop to meet the needs of the plant, which were estimated based on models developed by Nascimento et al. (1991), as shown in Table 1. 
Table 1. Nutrient parceling (doses of $\mathrm{K}$ and $\mathrm{P}$ ) for watermelon to cultivate Crimson Sweet, during the culture cycle, in the municipality of Garanhuns/PE.

\begin{tabular}{lccccccc}
\hline \multicolumn{7}{c}{ Ciclo } \\
\hline DAP & 1 & 2 & 3 & 4 & 5 & 6 \\
PDF & 1 a 15 & 16 a 30 & 31 a 45 & 46 a 60 & 61 a 75 & 76 a 90 & Total \\
NAPF & 3 & 16 & 30 & 28 & 21 & 2 & 100 \\
NDAF & 2 & 2 & 2 & 2 & 2 & 1 & 11 \\
\hline
\end{tabular}

$\mathrm{DAP}=$ days after planting PDF $=$ the combined demand percentage of potassium and phosphorus at each stage of the crop cycle $(\%)$; $\mathrm{NAPF}=$ number of fertirrigation applications within each stage of the crop cy cle, (admensional); NDAF= number of fertirrigation day $\mathrm{s}$ within each stage of the crop cycle, (days).

The irrigations were carried out through a drip located system and dripped by plant on a lateral line per row of plant. Self-compensating drippers were used with a flow rate of $4 \mathrm{Lh}-1$ at a service pressure of 0.2 $\mathrm{mPa}$, installed on the lateral line. The irrigation control was also carried out through tensiometers installed at 15,30 and $45 \mathrm{~cm}$, where a large part of the root zone is concentrated, and those installed at $30 \mathrm{~cm}$ were used to indicate the exact moment of irrigation and together with the readings of the tensiometers at $45 \mathrm{~cm}$, the calculation of the irrigation depth.

Thus, we tried to replace the moisture in the soil layer located in the root zone at field capacity. The readings of the tensiometers at a depth of $30 \mathrm{~cm}$ were performed in the morning and the data transferred to a spreadsheet based on information on the characteristic curve of soil water retention, using the model proposed by Van Genuchent (1980):

$\theta_{\mathrm{a}}=\theta_{\mathrm{r}}+\left\{\left(\theta_{\mathrm{s}}-\theta_{\mathrm{r}}\right) /\left[1+\left(\alpha \mathrm{x}_{\mathrm{m}}\right)^{\mathrm{n}}\right]^{\mathrm{m}}\right.$

Where: $\theta_{\mathrm{a}}=$ current humidity $\left(\mathrm{cm} 3 \mathrm{~cm}^{-3}\right)$; $\theta \mathrm{r}=$ residual humidity $\left(\mathrm{cm}^{3} \mathrm{~cm}^{-3}\right) ; \theta_{\mathrm{s}}=$ saturation humidity $\left(\mathrm{cm}^{3} \mathrm{~cm}^{-3}\right) ; \Psi \mathrm{m}=$ matrix potential $(\mathrm{kPa}) ; \alpha, \mathrm{m}$ and $\mathrm{n}=$ coefficients generated by the model. To determine the irrigation time, the following expression was used:

$\mathrm{T}=\frac{\mathrm{LLEgE}_{\mathrm{L}}}{\mathrm{Ea} \mathrm{Q}}$

Where: $\mathrm{LL}=$ irrigation depth $(\mathrm{mm}) ; \mathrm{T}=$ irrigation time $(\mathrm{h}) ; \mathrm{Eg}=$ spacing between emitters on the line $(\mathrm{m})$; $\mathrm{E}_{\mathrm{L}}=$ spacing between sidelines $(\mathrm{m}) ; \mathrm{Ea}=$ application efficiency, reached by uniformity test $(90 \%)$; $\mathrm{Q}=$ emitter flow $\left(\mathrm{L} \mathrm{h}^{-1}\right)$.

The design used was random blocks, with the treatments arranged in the factorial scheme $(3 \times 3)$ in subdivided plot, resulting in 9 treatments, with 3 repetitions, totaling 27 plots in the area of the experiment.

The treatments consisted of a combination of three doses of phosphorus fertilization and three doses of potassium fertilization. In the horizontal plots, the three phosphorus fertilization doses $\left(100,150\right.$ and $300 \mathrm{~kg} \mathrm{ha}^{-}$ ${ }^{1}$ of $\mathrm{P}_{2} \mathrm{O}_{5}$ ) were randomly allocated, corresponding to the following values applied to the soil according to soil chemical analysis $0.085,0.127$ and $0.255 \mathrm{~kg}$ of MAP per plant, respectively, and in the subplots the three potassium doses (50, 100 and $200 \mathrm{~kg} \mathrm{ha}^{-1}$ of $\mathrm{K}_{2} \mathrm{O}$ ), corresponding to $0.038,0.075$ and $0.150 \mathrm{~kg}$ of $\mathrm{KCl}$ per lant, respectively, were applied via irrigation water.

The evaluations involving the quality characteristics of the watermelon were carried out by collecting data referring to the two fruits from the first harvest, randomized chosen and free of any kind of deformities such as spots or any other apparent damage. Data collection was at the Vegetal Biology Laboratory of the Agrarian Academic Unit of Garanhuns (UAG) of the Rural Federal University of Pernambuco (UFRPE); where they were evaluated as quality components: SSTtotal soluble solids: obtained from the pulp, by refractometry with temperature correction, according to the methodology described by IAL (2008), the results were expressed in $\hat{A}^{\circ}$ Brix; TTA- titratable total acidity: obtained from the pulp, determined by neutralization titrometry, by titrating $10 \mathrm{~g}$ of pulp, homogenized and diluted to $100 \mathrm{~mL}$ in distilled water, with a standardized $1 \mathrm{~N} \mathrm{NaOH}$ solution, with a $\mathrm{pH}$ turning point 8.2 , in accordance with the method IAL (2008); the results were expressed in $\mathrm{g}$ of citric acid $100 \mathrm{~g}^{-1}$ of $0.1 \mathrm{~N}$ pulp $(\mathrm{NaOH})$; $\mathrm{pH}$ - hydrogen potential: obtained from the pulp, determined in samples consisting of $10 \mathrm{~g}$ of pulp in $100 \mathrm{ml}$ of distilled water, using the $\mathrm{pH}$ meter Hanna

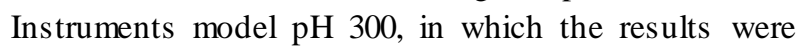
expressed in $\mathrm{pH}$ units, based on the method IAL (2008).

With the average data of all the biochemical characteristics of the fruits of the evaluated watermelon, analysis of variance (ANOVA) was performed according to the design described, using the Fischer " $F$ " test at the significance level of 0.01 or 0.05 probability (Banzatto and Kronka, 2013; Ferreira, 2019). To complement the study, this experiment seeks to determine the best dose of $\mathrm{K}$ and the dose of $\mathrm{P}$ to estimate the maximum yield of watermelon, based on the results of the analysis of the effects of the different fertilization doses, depending on the characteristics assessed for the production of watermelon fruit. This way, data were submitted to multiple regression 
analysis by making the response curve for each variable studied, in order to verify the best response of the evaluated characteristics of the fruit production according to the different doses of phosphorus and potassium fertilization from a multiple linear model, used Software Livre R, according to the following expression, (Ferreira, 2019):

$\mathrm{Y}(\mathrm{P}, \mathrm{K})=\mathrm{a}_{0}+\mathrm{a}_{1} . \mathrm{P}+\mathrm{a}_{2} \cdot \mathrm{K}+\mathrm{a}_{3} \cdot \mathrm{K} \cdot \mathrm{P}$

Where: $\mathrm{Y}(\mathrm{P}, \mathrm{K})=$ production variables analyzed for watermelon cultivation as a function of potassium and phosphorus doses in the soil; $\mathrm{P}=$ phosphorus doses $\left(100,150\right.$ e $300 \mathrm{~kg} \mathrm{ha}^{-1}$ de $\left.\mathrm{P}_{2} \mathrm{O}_{5}\right) ; \mathrm{K}=$ potassium doses $\left(50,100\right.$ e $200 \mathrm{~kg} \mathrm{ha}^{-1}$ de $\left.\mathrm{K}_{2} \mathrm{O}\right) ; \mathrm{a}_{0}, \mathrm{a}_{1}, \mathrm{a}_{2}$, e $\mathrm{a}_{3}=$ coefficients of the multiple linear model. Equation 3 is a function of production or maximum value to be estimated for each variable analyzed, having as independent variables the doses of $\mathrm{P}$ and $\mathrm{K}$, having as dependent variable the interaction between the $\mathrm{Y}$ doses $(\mathrm{P}, \mathrm{K})$. This can be obtained from the first derivative of Equation 3 and result equaling zero.

$\mathrm{VMv}=\frac{\partial \mathrm{Y}(\mathrm{P}, \mathrm{K})}{\partial \mathrm{P}, \partial \mathrm{K}}$

Where: Vmv the maximum marginal physical value of each variable analyzed, and $(\mathrm{e}(\partial \mathrm{Y}(\mathrm{P}, \mathrm{K})) /(\partial \mathrm{P}, \partial \mathrm{K})$ is derived from the function in relation to the analyzed variable.

\section{Results and Discussion}

It was observed by variance analyze for the variable total soluble solid (TSS), total titratable acidity (TTA) and hydrogen potential $(\mathrm{pH})$ of the watermelon juice and pulp, a significant statistical effect ( $\mathrm{p} \leq 1 \%$ ), by the $\mathrm{F}$ test, only for isolated doses of $\mathrm{K}$ and for interaction $\mathrm{P} \times \mathrm{K}$, on the total soluble solid variable (SST), indicating an existing dependence between these two studied factors (Table 2).

In Table 2, we can observe th different combinations (interactions) of $\mathrm{P}_{2} \mathrm{O}_{5}$ e $\mathrm{K}_{2} \mathrm{O}$ doses, did not significantly affect $(p>0.05)$ the chemicalquality of the fruit in relation to the mediumcontent of total titratable acidity (TTA) and acidity $(\mathrm{pH})$ of the pulp of watermelon fruits. It is also noted that the phosphorus dosages regardless of the potassium doses did not significantly affect $(p>0.05)$ the chemical quality of the fruits, when refer to the the total soluble solid variable (SST), $\mathrm{pH}$ and total titratable acidity (TTA) of the pulp of watermelon fruits.

Table 3 shows the results of the test of comparison of means by the Tukey test for the variable SST, for interaction between the doses of phosphorus and potassium. It appears that when the dose of phosphorus (P) is fixed at $100 \mathrm{~kg} \mathrm{ha}^{-1}$ the potassium doses $(\mathrm{K})$ are varied, there was an increase in the TSS up to the dose $100 \mathrm{~kg} \mathrm{ha}^{-1}$ of $\mathrm{K}$ and a reduction in the SST value in the presence of the highest dose of $\mathrm{K}\left(200 \mathrm{~kg} \mathrm{ha}^{-1}\right)$, which reinforces the proposition that the highest dose will not always present the largest increase in production

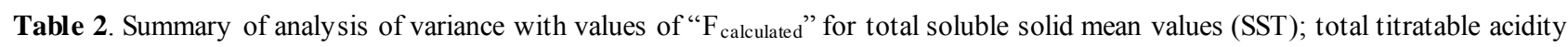
(TTA) and acidity $(\mathrm{pH})$ of the pulp of watermelon fruits, submitted to different doses of potassium and phosphorus via fertirrigation, Garanhuns/PE.

\begin{tabular}{|c|c|c|c|c|}
\hline \multirow{2}{*}{ Variation Sources } & \multirow{2}{*}{ GL } & \multicolumn{3}{|c|}{ Value of "Fcalculated" } \\
\hline & & SST $\left({ }^{\circ}\right.$ Brix $)$ & TTA & $\mathrm{pH}$ \\
\hline Blocks & 2 & $2.54 \mathrm{~ns}$ & $1.08 \mathrm{~ns}$ & $0.65 \mathrm{~ns}$ \\
\hline Doses of phosphorus (P) & 2 & $1.32 \mathrm{~ns}$ & $0.62 \mathrm{~ns}$ & $1.47 \mathrm{~ns}$ \\
\hline Erro a & 4 & & & \\
\hline Doses of potassium $(\mathrm{K})$ & 2 & $12.78 *$ & $0.11 \mathrm{~ns}$ & $0.40 \mathrm{~ns}$ \\
\hline Interaction $\mathrm{K} \times \mathrm{P}$ & 4 & $10.40 *$ & $1.00 \mathrm{~ns}$ & $0.75 \mathrm{~ns}$ \\
\hline \multicolumn{5}{|l|}{ Erro b } \\
\hline CV1 (\%) of plot & & 13.28 & 26.39 & 3.09 \\
\hline CV2 (\%) da Subplot & & 10.15 & 23.06 & 2.97 \\
\hline General mean & & 10.10 & 0.50 & 5.16 \\
\hline
\end{tabular}

$\overline{\mathrm{DF}}=$ degree of freedom; $* *$ and $*$ significant effect at 1 and $5 \%$ of probability by $\mathrm{F}$ test; respectively; "ns" non-significant.

Table 3. Test of comparison of means by the Tukey test for the total soluble solid (SST) content of the pulp of the watermelon fruits obtained, depending on the different levels of $\mathrm{K}$ and $\mathrm{P}$, Garanhuns/PE.

\begin{tabular}{lccc}
\hline Doses de fosfurum $(\mathrm{P})-\mathrm{kg} \mathrm{ha}^{-1}$ & \multicolumn{3}{c}{${\text { Doses de potassium }(\mathrm{k})-\mathrm{kg} \mathrm{ha}^{-1}}^{\mathrm{K} 200}$} \\
\cline { 2 - 4 } P100 & $10.40 \mathrm{a} \mathrm{B}$ & $12.08 \mathrm{a} \mathrm{B}$ & $6.10 \mathrm{aA}$ \\
P150 & $9.80 \mathrm{a} \mathrm{A}$ & $10.60 \mathrm{a} \mathrm{A}$ & $10.45 \mathrm{~b} \mathrm{~A}$ \\
P300 & $12.16 \mathrm{a} \mathrm{B}$ & $9.83 \mathrm{a} \mathrm{A}$ & $9.53 \mathrm{~b} \mathrm{~A}$ \\
\hline
\end{tabular}

Averages followed by the same letter, lowercase on the line (doses of P within the different doses of K) and uppercase on the column (doses of $\mathrm{K}$ within the different doses of $\mathrm{P}$ ), do not differ statistically from each other, by the Tukey test at 1 and $5 \%$ p robability 
Total soluble solids (SST) provide an indication of the amount of solids that are dis solved in the juice or fruit pulp, which means it is an important component in determining the quality of the fruit (Chitarra and Chitarra, 2005). The SST content is relevant in fruits, both for fresh consumption and for industrial processing, since high levels of these constituents on it results in less sugar added, less water evaporation time, less energy expenditure, besides higher product yield, which promotes savings during processing. The main soluble sugars present in the fruits are glucose, fructose and sucrose (Lima Neto et al., 2010; Jie et al., 2013).

The minimum SST content to obtain the acceptable flavor in watermelon is $9^{\circ}$ Brix. However, values starting at $10^{\circ}$ Brix are better accepted by the domestic market. It is known that there is a difference in the SST content according to the spatial distribution of the pulp, being greater in the central region, with a gradual reduction as it approaches the peel(Lima Neto et al., 2010). In the present study, the content of soluble solids in the pulp of the watermelon fruits, "Crims on Sweet" applied via irrigation water, it is observed that the values remained within the minimum limit required for commercialization, partly due to the fact of having been determined in juice from the mixture of different parts of the pulp. Ramos et al. (2009), working with different spacing in six watermelon cultivars, observed mean TSS levels of 7.79 and Lima Neto et al. (2010) observed mean TSS values of $8.56 \%$ in five watermelon varieties grown in Mossoró/RN.

Also in Table 3, it can be seen that the best results of the mean values for the SST content when analyzing the split doses of phos phorus within each dose of potassium( $\mathrm{P}$ $\mathrm{x} \mathrm{K})$ were obtained for the combination of doses $(300 \mathrm{~kg}$ ha-1 of $\mathrm{P}_{2} \mathrm{O}_{5} \times 50 \mathrm{~kg} \mathrm{ha}^{-1}$ of $\mathrm{K}_{2} \mathrm{O}$ ) with an average value of $12.16^{\circ}$ Brix, followed by doses $\left(100 \mathrm{~kg} \mathrm{ha}^{-1}\right.$ of $\mathrm{P}_{2} \mathrm{O}_{5} \times 100$ $\mathrm{kg} \mathrm{ha}^{-1}$ of $\mathrm{K}_{2} \mathrm{O}$ ) with an average value of $12.08^{\circ}$ Brix.

In general, the results are within acceptable limits and reported in studies evaluating the acidity of watermelon fruits, as reported by Lima Neto et al. (2010). The most commercially significant fruit characteristic is the sweet taste, indicated by the content of soluble solids, which for watermelon varies from 11 to $13{ }^{\circ}$ Brix in the most commercialized cultivars. In this work, the soluble solids content varied from 6.1 to $12.1{ }^{\circ}$ Brix. According to Andrade Junior et al. (2005), in high doses such as low nitrogen and potassium in the cultivation of fertigated watermelon, there is an imbalance in the relationship between nutrients in the soil (antagonism); affecting the absorption of nutrients by the plant, weakening it nutritionally.

A quantitative analys is of the response function of the watermelon crop to the simultaneous action of the factors $\mathrm{K}$ and $\mathrm{P}$ levels for SST of the estimated fruit pulp was most significantly represented by the multiple regression indicated in Eq. 4 and in Figure 1.
$\mathrm{Y}(\mathrm{P}, \mathrm{K})=11.92839-0.0000373 \mathrm{P}-0.022090 \mathrm{~K}+$ 0.00003858P.K with $\mathrm{R}^{2}=0.764$

Eq. (4)

There was a significant and positive influence of the interaction between $\mathrm{P}$ and $\mathrm{K}$ doses on the total soluble solid (TSS) content of the fruit pulp. For each response surface, the inflection point was determined analytically using the partial derivative of the statistical models selected for these characteristics. This point represents the $\mathrm{P}$ dose from which the increase in $\mathrm{K}$ doses results in decreases of SST (Figures 1A and 1B).

In the multiple regression analysis, it was observed that the fertirrigation for the interaction between the doses of $\mathrm{P}$ and $\mathrm{K}$ significantly influenced the SST (Figures 1A and 1B). Potassium fertirrigation caused the greatest variation for SST, between the 50 dose of $\mathrm{K}_{2} \mathrm{O}$ and the highest dose of $200 \mathrm{~kg} \mathrm{ha}^{-1}$, and was also responsible for the best response of the SST characteristic (12.6 ${ }^{\circ}$ Brix), with the minimum doses of $\mathrm{K}_{2} \mathrm{O}$ and fertirrigation with phosphorus of $300 \mathrm{~kg} \mathrm{ha}^{-1}$ of $\mathrm{P}_{2} \mathrm{O}_{5}$ (Figures 1A and 1B). Wrolow et al. (2004), evaluating the effect of phosphorus and potassium on the development of three legumes, observed a significant effect only for doses of $\mathrm{P}$ applied, and potassium did not influence the DM production of the legumes. Also by the results of the multiple regression analysis, observe that the fertirrigation for between the doses of $\mathrm{P}$ and $\mathrm{K}$, significantly influenced the SST (Figures 2A and 2B). Where the response function of the watermelon crop to the simultaneous action of the factors $\mathrm{P}$ and $\mathrm{K}$ levels for TTA of the fruit pulp estimated, was most significantly represented by the multiple regression indicated in Eq. 5 and in the Figure 2.

$\mathrm{Y}(\mathrm{P}, \mathrm{K})=0.36557+0.0006423 \mathrm{P}+0.0007335 \mathrm{~K}-$ 0.00000306P.K with $\mathrm{R}^{2}=0.812 \quad$ Eq. (5)

Figure 2 shows a significant regression model for TTA, indicating that the response surface model with multiple linear effects can be adopted to explain the watermelon production variables. Another important fact, which contributes to the acceptance of the model, is the fact that the regression deviation is not significant. Still in Figure 2, it can be seen that in conditions of low doses of Keven with the increase in the doses of $\mathrm{P}$, the TTA remain constant, but as the dose of $\mathrm{K}$ associated with the doses of $\mathrm{P}$ increased, the production has been increased. The fertilization of phosphorus and potassium influenced in an increasing and positive way for this characteristic. The maximum TTA value of the fruit pulp obtained by the multiple linear model, represented by the central trajectory of the TTA lines, was obtained for the combined doses of $300 \mathrm{~kg} \mathrm{ha}^{-1}$ of phosphorus and $200 \mathrm{~kg}$ $\mathrm{ha}^{-1}$ of potassium, which corresponded to the TTA value of the fruit pulp juice at an estimated maximum of 0.53 (Figure 2). These would be the recommended doses to obtain a higher TTA value. 
In the present study, the characteristic titratable total acidity (TTA) of the pulp juice was verified, showing little variation when applied to phosphorus doses of the order of 0.07 (0.47 to 0.54), however there was no significant difference when the values are compared with the other doses applied to the fertirrigation soil. A similar behavior was observed in relation to the application of potassium doses, with a small variation in the order of 0.02 ( 0.49 to 0.51 ). The highest TTA value was observed for the dose of $300 \mathrm{~kg} \mathrm{ha}^{-1}$ of $\mathrm{P}_{2} \mathrm{O}_{5}$, with a value of 0.54 and for the dose of $200 \mathrm{~kg} \mathrm{ha}^{-1}$ of $\mathrm{K}_{2} \mathrm{O}(0.51)$, as shown in Figure 2. These results are in agreement with that reported by Andrade Júnior et al. (2007) who cite watermelon, in general, values varying between 10 and $13 \%$.

According to Almeida et al. (2014), phosphate and potassium fertilization are of great importance for several fruit trees, since they interfere not only in the quantity produced, but also in the quality of the fruit. These nutrients have shown greater responses in terms of fruit quality. High doses of nitrogen reduce the content of soluble solids in fruit juice, while high doses of potassium have increased this content in most of the plants studied.

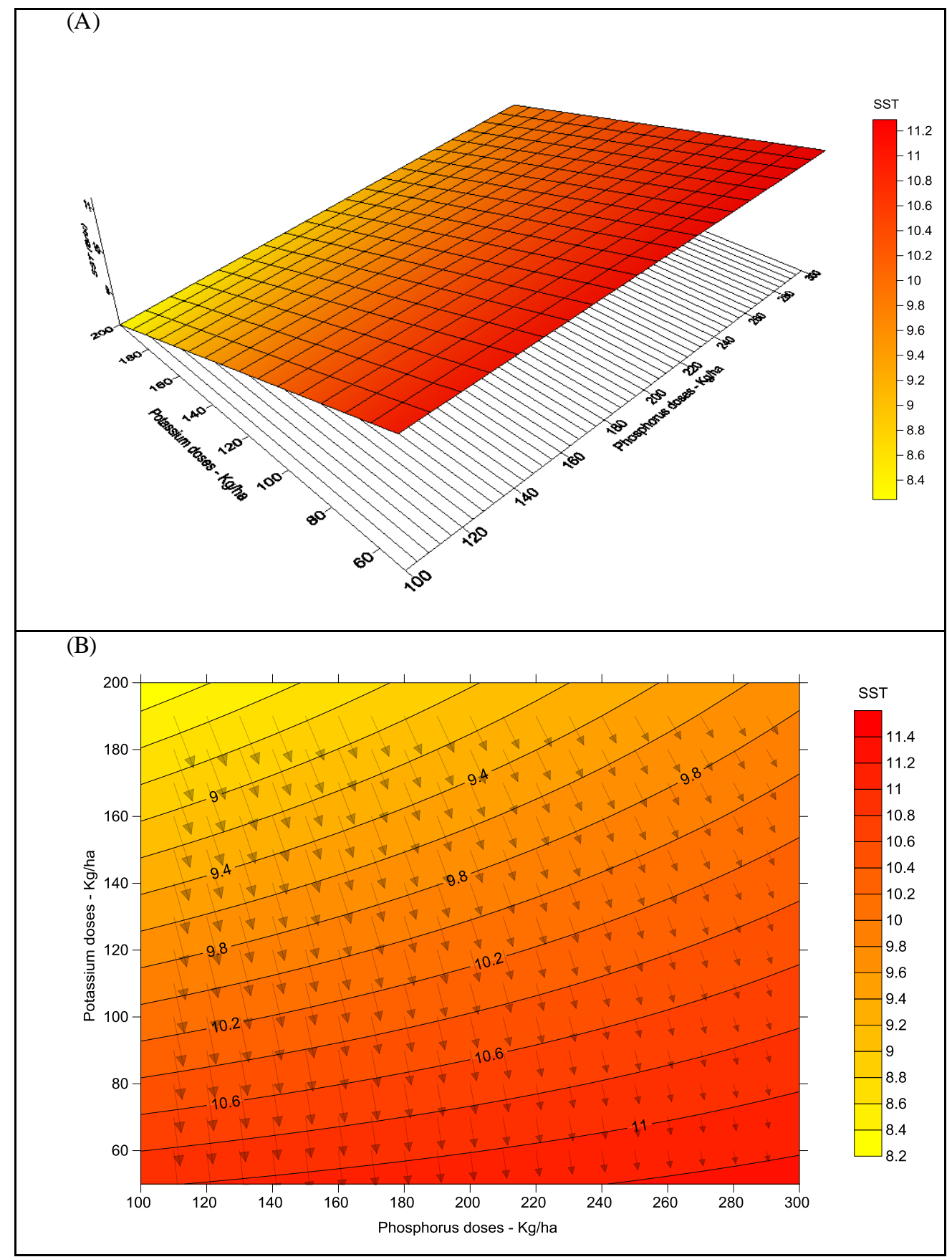

Figure 1. Response surface (A) and contour curve (B) the total soluble solids (SST) content of the fruit pulp, submitted to different levels of phosphorus and potassium via fertirrigation, Garanhuns/PE. 


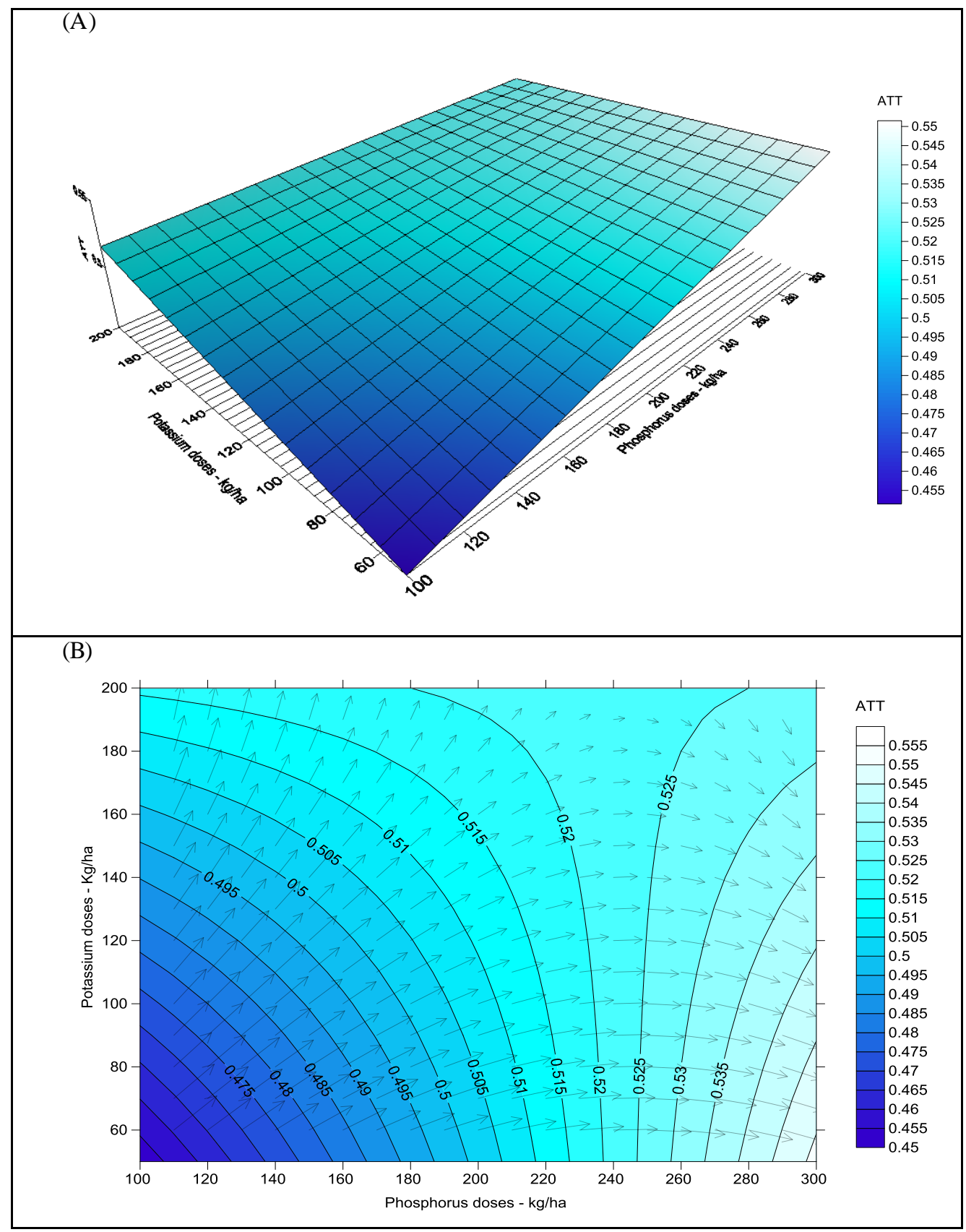

Figure 2. Response surface (A) and contour curve (B) the total titratable acidity (TTA) content of the fruit pulp, submitted to different levels of phosphorus and potassium via fertirrigation, Garanhuns/PE.

The acidity reflects the sum of the free organic acids. With ripening, there is a decrease in acidity due to the oxidation of acids in the tricarboxylic acid cycle due to respiration, however, in some cases, there may be a small increase in values with advancing maturation (Jie et al., 2013). Titratable acidity is used to express the acid or sour taste. For determining the quality of processed products, the most recommended method is $\mathrm{pH}$ (Morais et al., 2008; Lima Neto et al., 2010).

According to Ramos et al. (2009), the acidity due to organic acids is an important characteristic regarding the palatability of many fruits. With few exceptions, it decreases with maturation, due to the respiratory process or its conversion into sugars. The low acidity of watermelon fruits attracts many consumers whose average maximum value is observed in the range obtained in other studies and also within the $\mathrm{pH}$ range desirable by the consumer market. PH measures, in general, the acidity of fruits and foods, being an important indicator of the purpose of use of the cultivars (Martins et al., 2013). Fruits with a more acidic $\mathrm{pH}$ are destined for industry. Another important effect of $\mathrm{pH}$ is on the stability of anthocyanin and on the expression of fruit color. PH values below 5.0 are the property of watermelon for industrial use, whereas for fresh consumption, low acid fruits are preferable (Andrade Júnior et al., 2006). The $\mathrm{pH}$ most suitable for the culture is between 5.0 and 7.0. The multiple linear was the model that best fitted the data. (Figure 3) 


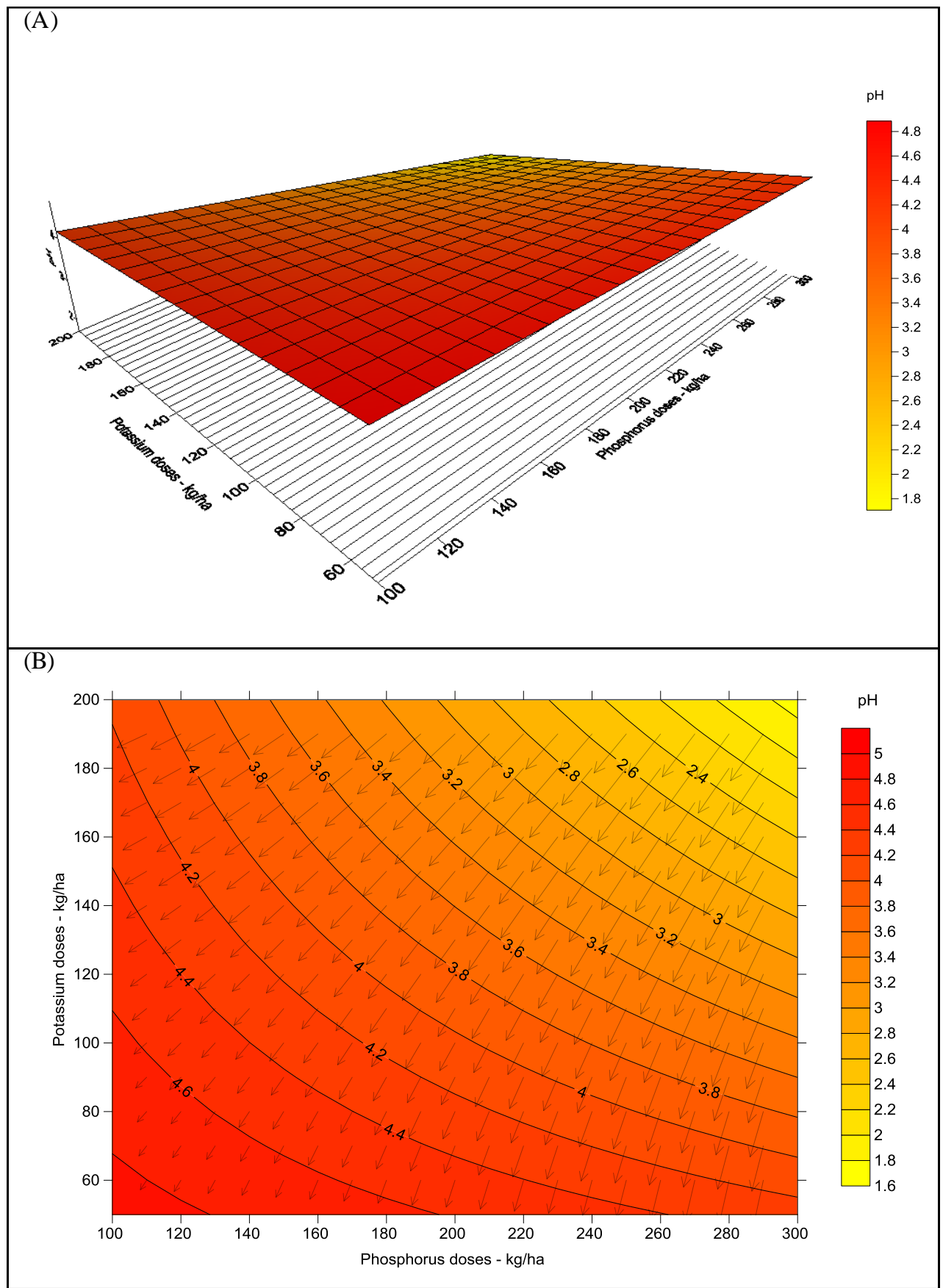

Figure 3. Response surface (A) and contour curve (B) the $\mathrm{pH}$ content of the fruit pulp, submitted to different levels of phosphorus and potassium via fertirrigation, Garanhuns/PE.

The multiple regression analysis showed that the response surface model chosen was significant by the $\mathrm{F}$ test at the level of $1 \%$ probability, meaning that the model may represent the $\mathrm{pH}$ variation in watermelon as a function of the different doses of $\mathrm{P}$ and $\mathrm{K}$, represented by multiple linear regression indicated in Eq. 6 and in Figure 3.

$$
\begin{aligned}
& \mathrm{Y}(\mathrm{P}, \mathrm{K})=5,1145+0,0001153 \mathrm{P}+0,001448 \mathrm{~K}+0,00000628 \mathrm{P} \cdot \mathrm{K} \\
& \text { with } \mathrm{R}^{2}=0,751
\end{aligned}
$$

The model that estimated a maximum $\mathrm{pH}$ value of the fruits (represented by the central trajectory of the arrows on the surface curve) was 4.88 corres ponding to the doses 100 and $50 \mathrm{~kg} \mathrm{ha}^{-1}$ of phosphorus and potassium, respectively. This estimated value is not similar to what was found by Morais et al. (2008), which ranged from 5.0 to 6.8. The results found for the $\mathrm{pH}$ characteristic are in agreement with those found by Oliveira et al. (2015) in watermelon marketed in Mossoró (RN) and by Feitosa et al (2009) in Ceará. Braga et al. (2011) also obtained higher results, for watermelon, with an average $\mathrm{pH}$ of 6.83. According to Andrade Júnior et al. (2007), plants well supplied with potassium have a high concentration in the tissues and a consequent reduction in water potential, which leads to a greater accumulation of water.

According to Malavolta (2006), the application of phosphate fertilizers via fertirrigation can cause desirable effects on the chemical properties of the soil, such as increasing the content of the nutrient applied in the soil 
and its availability to the plant, and undesirable effects, such as a possible increase in soil acidity, that is, a decrease in $\mathrm{pH}$. Phosphoric acid has been widely used in fertirrigation, as well as being a source of phosphorus, it reduces the $\mathrm{pH}$ of the water, preventing the precipitation of phosphorus by calcium (Zanini et al., 2007). Brito et al. (2000) detected significant responses of phosphorus sources in the commercial and total productivity of fruits, soluble solids and soluble solids/titrate acidity ratio in melon fruits, fruit from the same family as watermelon.

In Figure 3B, the outline of the central trajectory (represented by the highlighted arrows) as sociated with the contour curves of the $\mathrm{pH}$ variable as a function of the different doses of phosphorus and potassium, which allow visualizing the convergence to the optimal solution, can be seen growing and positive for this characteristic under study. Note the ideal $\mathrm{pH}$ values of the pulp of the fruits of the watermelon (between 5 and 6.80) converge to the values of doses of phosphorus and lower potassium.

\section{Conclusions}

According to the results, we can say that the best gains in the quality parameters of the watermelon fruit were registered in the interaction of doses $\left(300 \mathrm{~kg} \mathrm{ha}^{-1}\right.$ of $\mathrm{P}_{2} \mathrm{O}_{5}$ and $50 \mathrm{~kg} \mathrm{ha}^{-1}$ of $\mathrm{K}_{2} \mathrm{O}$ ) may be associated with the best distribution of $\mathrm{P}_{2} \mathrm{O} 5$ and $\mathrm{K}_{2} \mathrm{O}$ throughout the cycle, providing a more efficient use, since the requirements of these nutrients by plants vary with each stage of development.

And the different doses applied alone of phosphorus and potassiumdid not influence the quality parameters of the fruits: total titratable acidity (TTA) and acidity $(\mathrm{pH})$ of the fruit pulp, however these two parameters are within the standards of the consumed market. The best doses aiming at saving the inputs and less wear in the fertirrigation system are (150 kg ha-1 of $\mathrm{P}_{2} \mathrm{O}_{5}$ and $50 \mathrm{~kg} \mathrm{ha}^{-1}$ of $\left.\mathrm{K}_{2} \mathrm{O}\right)$.

\section{Authors' Contribution}

Antonio Ricardo Santos de Andrade contributed to the statistical analysis, and wrote the manuscript. Euler Soares Franco contributed to the writing of the manuscript in English, Hugo Orlando Carvallo Guerra contributed to guide the support and guidance in the agronomic area, management and cultural tracts. Sidnei Osmar Jadoski contributed by helping with statistics, creating the figures and writing the manuscript.

Adiel Felipe da Silva Cruz contributes to the assembly of the irrigation system, Maria Emanuele da Silva Ferreira and Edes Torres da Silva contributed to the collection of data in the field, Hammady Ramalho e Soares to tabulate the data to perform the statistics.

\section{Bibliographic References}

Almeida, E.I.B, Nóbrega G.N., Corrêa, M.C.M., Pinheiro, E.A.R., Araújo, N.A. 2014. Crescimento e marcha de absorção de micronutrientes para a cultivar de melancia Crimson Sweet. Revista Agroambiente, 8(1), 74-80.

Amaral, F.C.S. (Ed.). 2011. Sistema Brasileiro de Classificação de Terras para Irrigação: Enfoque na Região Semi-Árida. Rio de Janeiro: Embrapa Solos.

Andrade Júnior, A. S., Dias, N.S., Figueiredo Júnior, L. G. M., Ribeiro, V.Q., Sampaio, D.B. 2006. Produção e qualidade de frutos de melancia à aplicação de nitrogênio via fertirrigação. Revista Brasileira Engenharia Agrícola e Ambiental, 10(4), 836-841.

Andrade Junior, A.S., Dias, N.S., Figueiredo Junior, L. G. M., Daniel, R., Ribeiro, V.Q. 2005. Doses de potássio via fertirrigação na produção e qualidade de Frutos de melancia em Parnaíba, PI. Irriga, Botucatu, 10(3), 205-214.

Andrade Junior, A.S., Dias, N.S., Lira, R.B., Figueiredo Junior, L.G.M., Daniel, R. 2007. Frequência de aplicação de nitrogênio e de potássio via água de irrigação por gotejamento na cultura da melancia em Parnaíba/PI. Revista Agropecuária Científica no Semiárido, 3(1), 01-07.

\section{AGRIANUAL. ANUÁRIO ESTATÍSTICO DA} AGRICULTURA BRASILEIRA. 2017. São Paulo, FNP, 322324. https://www.ainfo.cnptia.embrapa.br (acessado 11 deagosto de 2021).

Araújo, W.F, Barros, M.M., Medeiros, R.D., Chagas, E.A., Neves, L.T.B.C. 2011. Crescimento e produção de melancia submetida a doses de nitrogênio. Revista Caatinga, Mossoró, 24(4), 80-85, 2011.

Azevedo, B.M., Fernandes, C.N.V., Nascimento Neto, J.R., Viana, T.V.A., Vasconcelos, D.V., Fernandes, C.N.D. 2016. Frequência da fertirrigação fosfatada na produtividade da Cultura da melancia Irriga, Botucatu, 21(2), 257-268.

Banzatto, D.A., Kronka, S.N. 2013. Experimentação agrícola. 4. ed. Jaboticabal-SP: Funep.

Braga, D.F., Negreiros, M.Z., Freitas, F.C.L., Grangeiro, L.C., Lopes, W.A.R. 2011. Crescimento de melancia "mickylee" cultivada sob fertirrigação. Revista Caatinga, Mossoró, 24(3), 49-55.

Brito, L.T.L., Soares, J.M., Faria, C.M.B., Costa, N.D. 2000. Fontes de fósforo aplicadas na cultura do melão via água de irrigação. Revista Brasileira de Engenharia Agrícola e Ambiental, Campina Grande, 4(1), 19-22.

Castilhos, L.F.F. 2012. Dossiê técnico cultivo de melão e melancia, Instituto de Tecnologia do Paraná http://www.respostatecnica.org.br/dossie-

tecnico/downloadsDT/NTY5Nw (acessado em: 11 agosto de 2021).

EMBRAPA. EMPRESA BRASILEIRA DE PESQUISA AGROPECUÁRIA. 1999. Centro nacional de pesquisa de solos. Sistema brasileiro de classificação de solos. Rio de Janeiro, CNPS. https://www.embrapa.br (acessado 12 agosto de 2021). 
Chitarra, M.I.F., Chitarra, A.B. 2005. Pós-colheita de frutos e hortaliças: fisiologia e manuseio. Editora. UFLA, Lavras.

Dias, R.C.S., Resende, D.M., Costa, N.D. 2001. Cultura da melancia. Petrolina: Embrapa Semi-Árido, 20p. (Circular Técnica, 63). https://www.researchgate/Cultura_da_Melancia (acessado 12 de agosto de 2021).

Feitosa, T., Garruti, D.S., Lima, J.R., Mota, S., Bezerra, F.M.L. 2009. Qualidade de frutos de melancia produzidos com reúso de água de esgoto doméstico tratado. Revista Tecnologia, Fortaleza, 30(1), 53-60.

Ferreira, D.F. 2019. SISVAR: a computer analy sis system to fixed effects split plot type designs. Revista Brasileira de Biometria, 37(4), 529-535. DOI: https://doi.org/10.28951/rbb.v37i4.450

FAOSTAT. FOOD AND AGRICULTURE ORGANIZATION OF THE UNITED NATIONS. 2019. Watermelon production in Brazil from 2013 to 2019. http://www.fao.org/faostat/en/\#data/QI (acessado 22 de abril de 2021).

IAL. INSTITUTO ADOLFO LUTZ. 2008. Métodos físicoquímicos para análise de alimentos. São Paulo, Instituto Adolfo Lutz. https://www.docsity.com/pt/metodos-fisico-quimicospara-analise-de-alimentos-ial-2004/4728670/ (acessado 12 de agosto de 2021).

IBGE. INSTITUTO BRASILEIRO DE GEOGRAFIA E ESTATÍSTICA. 2016. Produção Agrícola Municipal, 2015. Rio de Janeiro. http://www.sidra.ibge.gov.br (acessado 10 de abril de 2021).

Jie, D., Xie, L., Fu, X., Rao, X., Ying, Y. 2013. Variable selection for partial least squares analysis of soluble solids content in watermelon using near-infrared diffuse transmission technique. Journal of Food Engineering, 118(4), 387-392.

Lima Neto, I.S., Guimaraes, I.P., Batista, P.F., Aroucha, E.M.M., Queiroz, M.A. 2010. Qualidade de frutos de diferentes variedades de melancia provenientes de Mossoró-RN. Revista Caatinga, Mossoró, 23(4), 14-20.

Lucena, R.R.M., Negreiros, M.Z., Medeiros, J.F., Grangeiro, L.C., Marrocos, S.T.P. 2011. Crescimento e acúmulo de macronutrientes em melancia 'Quetzale' cultivada sob diferentes níveis de salinidade da água de irrigação. Revista Caatinga, Mossoró, 24(1), 34-42.

Malavolta, E. Manual de nutrição mineral de plantas. Editora Ceres, São Paulo, 2006.

Martinhão, D., Sousa, G., Lobato, E. 2004. Adubação Fosfatada em Solos da Região do Cerrado. In: Yamada, T., Abdalla, S.R.S. (Ed.). Fósforo na Agricultura Brasileira. Potafós, Piracicaba.
Martins, J.C.P., Aroucha, E.M.M., Medeiros, J.F., Nascimento, I.B., Paula, V.F.S. 2013. Características pós-colheita dos frutos de cultivares de melancia, submetidas à aplicação de bioestimulante. Revista Caatinga, 26(2), 18-24.

Morais, N.B., Bezerra, F.M.L., Medeiros, J.F., Chave, S.W.P. 2008. Resposta de plantas de melancia cultivadas sob diferentes níveis de água e de nitrogênio. Revista Ciência Agronômica, 39(3), 369-377.

Nascimento, V.M., Fernandes, F.M., Morikawa, C.K., Laura, V.A., Oliveira, C.A. 1991. Produção de matéria seca e absorção de nutrientes pela melancia (Citrullus lanatus (thumb) Masnf.) em um Latossolo da região do cerrado. Científica, 19(2), 85-91.

Oliveira, J.B., Grangeiro, L.C., Sobrinho, J.E., Moura, M.S.B., Carvalho, C.A.C. 2015. Rendimento e qualidade de frutos de melancia em diferentes épocas de plantio. Revista Caatinga, Mossoró, 28(2), 19-25.

Ramos, A.R.P, Dias, R.C.S., Aragão, C.A. 2009. Densidades de plantio na produtividade e qualidade de frutos de melancia. Horticultura Brasileira, 7(4), 560-564.

SENAR. SERVIÇO NACIONAL DE APRENDIZAGEM RURAL. 2019. Irrigação: fertirrigação e reúso de efluentes. Coleção SENAR- $\quad 254, \quad$ Brasília. https://www.cnabrasil.org.br/assets/arquivos/254-IRRIGA.pdf (acessado 12 de agosto de 2021)

Souza, M.S., Medeiros, J.F., Silva, M.V.T., Silva, O.M.P., Chaves, S.W.P. 2014. Estado nutricional da melancia fertirrigada com doses de nitrogênio e fósforo. Semina: Ciências Agrárias, 35(4), 2301-2316.

Van Genuchten, M.T. 1980. A closed form equation for predicting the hydraulic conductivity of unsaturated soils. Soil Science Society of America Journal, 44(5), 892-898. DOI: https://doi.org/10.2136/sssaj1980.03615995004400050002x

Villas Bôas, R.L., Antunes, C.L., Boareto, A.E., Sousa, V.F., Duenhas, L.H. 2001. Perfil da pesquisa e emprego da fertirrigação no Brasil. In: Folegatti, M.V., Casarini, E., Blanco, F.F., Brasil, R.P.C., Resende, R.S. (eds.). Fertirrigação: Flores, frutas e hortaliças. Guaíba: Agropecuária, p. 71-103.

Wrolow, R.H., Misture, C., Coelho, R.W., Siewerdt, L., Zonta, E.P. 2004. Efeito do fósforo e do potássio sobre o desenvolvimento e a nodulação de três leguminosas anuais de estação fria. Revista Brasileira de Zootecnia, 33(6), 2224-2230.

Zanini, J.R., Barreto, A.K.G., Foratto, L.C., Natale, W. 2007. Distribuição de fósforo no bulbo molhado, aplicado via fertirrigação por gotejamento com ácido fosfórico. Engenharia Agrícola, Jaboticabal, 27(1), 180-193 